\title{
PENERAPAN BIMBINGAN KELOMPOK UNTUK MENGEMBANGKAN KONSEP DIRI SISWA (PENELITIAN TINDAKAN KELAS PADA SISWA KELAS X-IPS 4 SMA NEGERI 3 AMBON)
}

\author{
Djahra Fataruba \\ SMA Negeri 3 Ambon \\ Email: djahrafataruba@gmail.com
}

\begin{abstract}
Abstrak
Di usia remaja, peserta didik berada pada masa pencarian identitas diri. Mereka sedang mencari-cari gambaran tentang siapa dirinya, atau penilaian tentang dirinya. Penilaian terhadap diri sendiri merupakan prediksi untuk mempersiapkan diri sendiri. Berbagai penelitian yang dilakukan para ahli menunjukkan, bahwa pandangan individu terhadap dirinya sendiri sangat menentukan keberhasilan yang akan dicapai. Pandangan dan sikap individu terhadap dirinya inilah yang dikenal dengan konsep diri.

Penelitian ini difokuskan kepada Penerapan Bimbingan Kelompok untuk mengembangkan Konsep Diri Siswa dalam rangka menjawab pertanyaan tentangbagaimana siswa pada kelas X IPS 4 SMA Negeri 3 Ambonmampu menerapkan bimbingan kelompok yang diberikan oleh Guru, guna mengembangkan konsep diri siswa.

Metode penelitian yang digunakan adalah penelitian tindakan (action research). Teknik pengumpulan data yang digunakan antara lain : Observasi, jenis observasi yang digunakan adalah observasi partisipasi yaitu kondisi dimana peneliti benar-benar ikut serta (terlibat) dalam penerapan bimbingan kelompok untuk mengembangkan konsep diri siswa.

Hasil penelitian menunjukkan bahwa, penerapan bimbingan kelompok dapat mengembangkan konsep diri pada siswa kelas X IPS-4 SMA Negeri 3 Ambon. Oleh karena itu, bimbingan kelompok dapat direkomendasikan sebagai salah satu solusi dalam membantu mengembangkan konsep diri sisiwa.
\end{abstract}

\section{Kata kunci: bimbingan kelompok, konsep diri}

\section{A. PENDAHULUAN}

Dalam era milinea ini, kita sedang memasuki suatu abad baru yang banyak menimbulkan perubahan dan kemajuan, sekaligus menjadi tantangan.Tantangan akibat perubahan dan kemajuan yang cepat, terjadi baik pada aspek sosial, budaya, dan
teknologi.Permasalahan-permasalahan yang dihadapi akibat perubahan tersebut semakin komplek, baik masalah pribadi, sosial, ekonomi, budaya dan lain-lain.Untuk menghadapi tantangan ini diperlukan kesiapan individu secara fisik dan mental, agar lebih mampu mengatasi 
berbagai hal dalam mencapai kesuksesan. Bagaimana kita menghadapi tantangan yang ada bisa dimulai dengan berempati, mengubah cara pandang, mengelola emosi dan mengambil resiko. Apabila tidak memiliki referensi nilai, fokus yang positif, dan harga diri maka akan timbul kesulitan dan menemukan sumber daya batiniah yang diperlukan untuk menangani tantangan

-tantangan yang beragam dalam kehidupan.

Peserta didik di tingkat SMA berada pada usia remaja sebagai individu yang sedang berkembang mencapai taraf perkembangan pribadi secara optimal dalam berbagai aspek kehidupan dan berada pada masa pencarian identitas diri. Mereka sedang mencari-cari gambaran tentang siapa dirinya, atau penilaian tentang dirinya. Penilaian terhadap diri sendiri merupakan prediksi untuk mempersiapkan diri sendiri. Berbagai penelitian yang dilakukan para ahli menunjukkan, bahwa pandangan individu terhadap dirinya sendiri sangat menentukan keberhasilan yang akan dicapai.

Menurut Burns pandangan dan sikap individu terhadap dirinya inilah yang dikenal dengan konsep diri.Konsep diri merupakan pandangan menyeluruh individu tentang totalitas dari diri sendiri mengenai karakteristik kepribadian, nilai-nilai kehidupan, prinsip kehidupan, moralitas, kelemahan dan segala yang terbentuk dari segala pengalaman dan interaksinya dengan orang lain.

Konsep diri penting artinya karena individu dapat memandang diri dan dunianya, mempengaruhi tidak hanya individu berperilaku, tetapi juga tingkat kepuasan yang diperoleh dalam hidupnya.Setiap individu pasti memiliki konsep diri, tetapi mereka tidak tahu apakah konsep diri yang dimiliki itu negatif atau positif. Siswa yang memiliki konsep diri positif ia akan memiliki dorongan mandiri lebih baik, ia dapat mengenal serta memahami dirinya sendiri sehingga dapat berperilaku efektif dalam berbagai situasi. Konsep diri positif bukanlah suatu kebanggaan yang besar tentang diri tetapi berupa penerimaan diri.Siswa yang memiliki konsep diri positif dapat memahami dan menerima sejumlah faktor yang sangat bermacam-macam tentang dirinya sendiri. Dalam hal ini siswa dapat menerima dirinya secara apa adanya dan akan mampu mengintrospeksi diri atau lebih mengenal dirinya, serta kelemahan dan kelebihan yang dimiliki. Namun siswa yang memiliki konsep diri negatif, ia tidak memiliki perasaan kestabilan dan keutuhan diri, juga tidak mengenal diri baik dari segi kelebihan maupun kekurangannya atau sesuatu yang ia hargai dalam hidupnya.

Masalah dan kegagalan yang dialami peserta didik disebabkan oleh sikap negatif terhadap dirinya sendiri, yaitu menganggap dirinya tidak berarti. Individu yang memiliki konsep diri yang negatif adalah individu yang mudah marah dan naik pitam serta tidak tahan terhadap kritikan yang diterimanya, dengan kata lain individu kurang menerima peraturan/norma yang telah ditetapkan, sehingga ada sifat membrontak pada dirinya yang 
menentang aturan tersebut. Perilaku siswa yang menyimpang dari aturan yang berlaku di sekolah disebabkan oleh pandangan negatif terhadap dirinya, yaitu dirinya tidak mampu menyelesaikan tugasnya.

Sekolah merupakan salah satu tempat pendidikan bagi siswa untuk dapat mengembangkan diri melalui layanan bimbingan dan konseling. Layanan bimbingan kelompok merupakan salah satu jenis layanan yang dianggap tepat untuk memberikan kontribusi pada siswa untuk mengembangkan konsep diri positif.

Layanan bimbingan kelompok merupakan proses pemberian informasi dan bantuan pada sekelompok orang dengan memanfaatkan dinamika kelompok guna mencapai suatu tujuan tertentu. Layanan yang diberikan dalam suasana kelompok selain itu juga bisa dijadikan media penyampaian informasi sekaligus juga bisa membantu siswa menyusun rencana dalam membuat keputusan yang tepat sehingga diharapkan akan berdampak positif bagi siswa yang nantinya akan menumbuhkan konsep diri yang positif. Selain itu apabila dinamika kelompok dapat terwujud dengan baik maka anggota kelompok saling menolong, menerima dan berempati dengan tulus.

Bimbingan kelompok merupakan lingkungan yang kondusif yang memberikan kesempatan bagi anggotanya untuk menambah penerimaan diri dan orang lain, memberikan ide, perasaan, dukungan bantuan alternatif pemecahan masalah dan mengambil keputusan yang tepat, dapat berlatih tentang perilaku baru dan bertanggung jawab atas pilihan yang ditentukan sendiri. Suasana ini dapat menumbuhkan perasaan berarti bagi anggota yang selanjutnya juga dapat menambah konsep diri yang positif.

\section{B. METODE PENELITIAN}

Penerapan Bimbingan Kelompok untuk Mengembangkan konsep diri siswa dengan menggunakan penelitian tindakan dilakukan dalam beberapa tahapan. Secara umum, tahapan penelitian tindakan dapat dilihat pada bagan berikut : 
Gambar.1

Tahapan Penelitian Tindakan (Sumber : Hidayat\& Badrujaman, 2012)

Siklus I

Kegiatan Pengumpulan Data

Analisissituasi: Adanya permasalahan yang dialami siswa sehubungan dengan konsep diri.

Hal-hal yang direncanakan :

- Penyusunan rencana Tindakan (scenario bimbingan kelompok)

- Membuat satuan layanan bimbingan kelompok

- Instrument pengumpulan data

- Format evaluasi konsep diri

- Indikator keberhasilan siklus I

Perencanaan

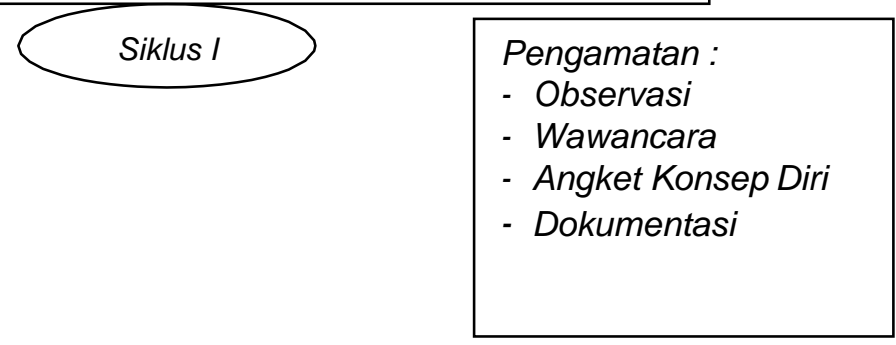

Pengamatan

1. Analisis Situasi

Sebelum menyusun rencana penelitian, terlebih dahulu peneliti menganalisis situasi dengan melakukan kegiatan pengumpulan data awal atau studi pendahuluan di kelas X IPS4 SMA Negeri 3 Ambon.Tujuannya adalah untuk mendapatkan gambaran konsep diri siswa.

2. Rancangan Siklus Penelitian

a. Tahap Perencanaan

Kegiatan ini merupakan prosedur awal dari sebuah siklus. Langkah perencanaan yang dilakukan adalah :

1). Merencanakan tindakan yang akan diterapkan (skenario bimbingan kelompok).

2). Membuat satuan layanan bimbingan kelompok

3). Menyiapkan instrumen pengumpulan data

4). Mengembangkan format evaluasi (skala penilaian)

5). Menetapkan indikator keberhasilan siklus I

b. Tahap Tindakan

Dalam penelitian ini, tindakan yang akan diterapkan sebagai realisasi dari perencanaan di atas. Tahap tindakan disusun berdasarkan tahapan- tahapan dalam bimbingan kelompok meliputi:

1). Tahap Pembentukan

2). Tahap Peralihan

3). Tahap Kegiatan

4). Tahap Pengakhiran

c. Tahap Pengamatan/ Observasi Tahap pengamatan dilakukan untuk mengamati proses bimbingan kelompok dan mengumpulkan informasi tentang proses bimbingan yang 
dilakukan peneliti sesuai dengan tindakan yang telah disusun. Pengamatan dilakukan oleh guru bimbingan dan konseling dan dosen PDS selama proses kegiatan bimbingan kelompok berlangsung.

d. Tahap Refleksi

Pada setiap akhir satu siklus penerapan bimbingan kelompok, hasil pengumpulan data observasi, wawancara dan angket kemudian direfleksikan, dicek ulang dan dianalisis serta diinterpretasikan, kemudian disimpulkan pemaknaannya. Hasil refleksi tersebut digunakan untuk perencanaan tindakan disiklus selanjutnya.

\section{KESIMPULAN DAN SARAN}

1. Kesimpulan

Berdasarkan hasil penelitian yang diperoleh, maka dengan demikian dapat disimpulkan bahwa :

$\begin{array}{lr}\text { a) Penerapan } & \text { bimbingan } \\ \text { kelompok } & \text { dapat }\end{array}$ mengembangkan konsep diri pada siswa kelas X IPS-4 SMA Negeri 3 Ambon.

b) Bimbingan kelompok dapat direkomendasikan sebagai salah satu solusi dalam membantu mengembangkan konsep diri sisiwa.

2. Saran

a) Guru Bimbingan dan Konseling

Hasil penelitian ini direkomendasikan bagi guru bimbingan konseling/konselor sekolah terlebih khusus guru bimbingan dan konseling di SMA Negeri 3 Ambon agar dapat diintegrasikan ke dalam komponen program bimbingan dan konseling di sekolah, sehingga menjadi program preventif untuk mengembangkan konsep diri siswa.

b) Siswa

Melalui hasil penelitian ini, diharapkan agar siswa dapat lebih giat lagi belajar dan meningkatkan bimbingan kelompok sebagai sarana untuk mengembangkan konsep diri siswa.

\section{DAFTAR PUSTAKA}

Burns, R. B. (1993). Konsep Diri:

Teori,

Pengukuran,Perkembangan, dan Perilaku. (Alih bahasa:

Eddy). Jakarta: Arcan.

Centi, J Paul (1993). Mengapa

Rendah Diri? Yogyakarta :

Kanisius

Hurlock Elizabeth (2005). Psikologi

Perkembangan Anak Jilid 2,

Jakarta : Erlangga.

Hidayat \& Badrujaman (2012).

Penelitian Tindakan dalam

Bimbingan Konseling. Jakarta:

PT Indeks

Jallaludin Rahmat, (2007) Psikologi

Komunikasi,Bandung : Remaja

Rosdakarya

Nurihsan, Achmad Juntika. (2006).

Bimbingan dan konseling dalam

Berbagai

Latar 
Kehidupan. Bandung: PT Refika Aditama.

Prayitno. (2004). Layanan Bimbingan

kelompok. Padang : Fakultas

Ilmu Pendidikan Universitas

Negeri Padang.

Sukardi, Dewa Ketut (2002).

Pengantar Pelaksanaan

Konseling di Sekolah. Jakarta :

Rineka Cipta 